\title{
The Effect of Collegial School Management on Improvement of Students' skills
}

\author{
Nazmi Xhomara
}

Luarasi University, Department of Mathematics and Statistics, Faculty of Information Technology and Innovation, Tirana, Rr. e Elbasanit, Nd. 59, H. 1, AL-1010, Albania, nazmi.xhomara@luarasi-univ.edu.al

Abstract. The study aims to investigate the effect of collegial school management on the prevention of disruptive behaviors and students' life skills. A quasi-experimental research design, a structured questionnaire, and the cluster random samples were used in the study. It is found that school management increase the prevention of disruptive behaviors and students' life skills, and collegial school management predicts the prevention of disruptive behaviors and students' life skills.

Keywords: school management, collegial school management, formal school management prevention of disruptive behaviors, students' life skills.

\section{Introduction}

Collegial school management is supposed to be one of the important variables that influence the prevention of disruptive behaviors and students' life skills. The concept management implied control over others, to get things done (Onzonol, 2010). School management should be concerned with the aims of education, that provide the essential sense of direction of children's services (Bush, 1986; 1995; 2003). School management can develop the competencies and civic skills the students need as they move toward adulthood (Kumar, 2011; Payne \& Edwards, 2010). School management consists not only of the process of effectively operating, but also of developing and innovation of an educational organization established to approach the public demand (Basaran, 1996; cited by Tas, 2011). 
The main variables of interest in the study are collegial school management, selected to study as an independent variable and prevention of disruptive behaviors and students' life skills as dependent variables. School management is selected to use as a manipulated variable, collegial vs formal style. The conceptual definition of variables selected in the study was as follows. Collegial models advocate teacher participation in decision-making at school that often provides the setting for development of political activity or "top-down" decision-making (Bush, 2003). Main features of collegial management including: (1) goals are determined at institutional level, (2) process by which goals are determined is set by agreement between leader and teachers, (3) decisions are based on agreed goals, (4) there is an objective reality lateral, (5) accountability is blurred by shared decision making, (6) and is related to participative leadership. Prevention of disruptive behaviors or classroom management involves not only effective teaching, supervision and facilitation, but also the maintenance of academic discipline (Padmaja, 2012). Life skills include academic skills, such as curriculum' knowledge, skills, attitudes and values, as well as psychosocial competencies and interpersonal skills, such as self-development, self-management, social-emotional learning, communication skills, self- motivating and managing others, and effective group leadership (Marilyn, 2013; Jagpreet, 2015). The study aims to investigate the effects of school management on the prevention of disruptive behaviors and students' life skills.

\section{Literature review}

\section{Collegial school management and prevention of disruptive behaviors}

The first assumption of this study is that collegial school management impacts the prevention of disruptive behaviors. The creation of the learning environment by collegial school management may improve the prevention of disruptive behaviors or classroom management (Wirussawa et al., 2016; Akin et al., 2016). There are significant correlations between the teaching experience, learning tasks, and prevention of disruptive behaviors or classroom management (Kinloch, 2013; Mac Cobb et al., 2014). Senlik (2013) indicates that class size, grade and school-level significantly influenced a few observable behaviors in the classroom, and class size and homework management directly impact classroom management (Handal et al., 2015; Xu, 2012). Collegial school management is related positively to the prevention of disruptive behaviors (Prendergast and O'Meara, 2016; Deckman, 2017). Babatunde (2015) revealed that restrictive prevention of disruptive behaviors was positively related to children's externalizing behaviors; furthermore, students in urban schools show more externalizing behaviors than students in rural ones (Shavega, van Tuijl, \& Brugman, 2015). There is a significant influence of instructional and transformational leadership on the prevention of disruptive behaviors, and effective teaching and learning through leadership and management requires principals to be 
trained (Dou et al., 2017; Bush \& Glover, 2016; Mampane, 2017). Therefore, it is important to study the relationship between collegial school management and the prevention of disruptive behaviors.

\section{Collegial school management and students' life skills}

The second assumption of this study is that collegial school management impact students' life skills. The management of competencies, conflict resolution training, intercultural communicative mpetence, and small-group curriculum increased students' learning and their life skills (Oyono, 2016; Jensen et al., 2015; Akgun \& Araz, 2014; Lakova \& Chaklikova, 2016; Ohrt et al., 2015), meanwhile teaching management support students' knowledge and skills (Wang et al., 2016). Collegial school management, a new curriculum, teachers' pedagogical content knowledge, and social-emotional learning instruction led to gains in students' skills (Hoidn \& Olbert-Bock, 2016; Kunter et al., 2013; Kendziora \& Yoder, 2016). Management strategies support the students to participate in the classroom and to gain new knowledge and skills (Schulze, 2016), and students who participated in collaborative groups acquired decision-making skills (Zhang et al., 2016). Tsai and Liu (2015) revealed that collegial school management, as well as responsibilities among teachers, influence communication and interpersonal skills (Abulibdeh, 2013). The significant positive relationship exists between academic students' skills and collegial school management, as well as employability skills (Harris, 2013; Kraebber and Greenan, 2012; Hadromi \& Soesanto, 2015).

The classroom management (Reinke et al., 2014), self-management and regulation strategy (Thompson, 2014), students' self and social-awareness, self and relationshipmanagement (Ee \& Ong, 2014), as well as camps and field trips (Breslin et al., 2012) fostering classroom management and student skills and competences. Robacker et al. (2016) pointed out that formal school management influence on lower students' knowledge and skills, meanwhile, Briesch et al. (2013) suggest a moderate to the strong effect of collegial school management intervention for increasing student engagement and their life skills. Delman (2011) pointed out that good management will enhance the instruction, and was the only predictor of students learning outcomes and their life skills (Riaz, 2015). The collegial school management was positively associated with students' skills (Yang et al., 2016); meanwhile, collegial school management and affective attitude appearing as two significant predictors in students' life skills (Xu \& Wu, 2013; Ifegbesan, 2010). Thus, the present study will investigate the school management as a substantial variable influencing the prevention of disruptive behaviors, and students' life skills. Therefore, it is important to study the relationship between collegial school management and students' life skills. 


\section{Theoretical framework and hypothesis development}

\section{Conceptual framework}

Collegial school management could be regarded as an input of constructivism that viewed the school as a miniature democratic society (Dewey, 1934). Constructivism treats the learners as actively involved in thinking and learning (Howe \& Berv, 2000), where they participate in generating understanding (Brooks \& Brooks, 1993). Constructivism was used as a basis to conceptualize the research framework (Figure 1).

The conceptual framework of the study was based on a systematic and critical review of evidence about school management, prevention of disruptive behaviors and students' life skills variables. The criteria used to select articles for literature review include: (1) they involve studying the relationship between interested variables, (2) all of them are written in English, (3) mainly of them are published not earlier than 10 years. 19 papers selected in the first phase were rejected because of the lack of coherence with the aim and research hypothesis. The review includes empirical research through ERIC, EBSCO, and SAGE using "collegial school management," "prevention of disruptive behaviors," and "students' life skills" as keywords. Figure 1, summarizing the framework, proposes a set of relationships among collegial school management, and prevention of disruptive behaviors and students 'life skills.

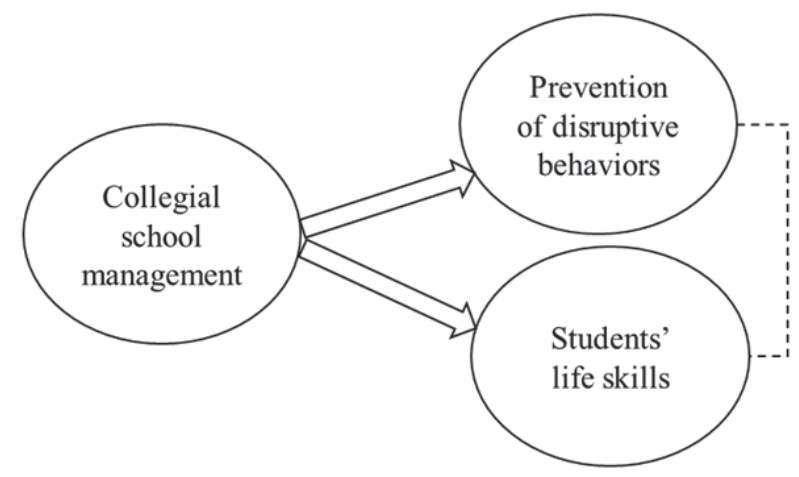

Figure 1: Conceptual framework

\section{Collegial school management}

Collegial school management is meant to be an important variable that effects the prevention of disruptive behaviors. A school manager has to establish positive relations with teachers, students, administrative staff as well as students' parents at school (Kaya, 1991; cited by Tas, 2011), and the setting of a well-organized school structure requires communication between school manager and all of the other school actors (Tas, 2011). Collegial school management is more efficient than formal management (Walk, 2003), 
as well as the formal model of management is misaligned with the demands of a 21st-century global knowledge-based economy (Hamel \& Breen, 2008). The collegial school management studied ethics, and senior management improves learning, teaching, and attainment (Conn, 2002; Sanjoy et al., 2014; Turner et. al., 2007); meanwhile, Hamel (2008) views management as a mature social technology that is now imperiling the adaptability of organizations. Students who received collegial school management, as well as family help, reported more positive attitudes toward school as well as toward their life skills (Xu, 2006; Xu \& Corno, 2003; Xu \& Corno, 2006). Reddy, Dudek, Rualo, and Fabiano (2016) demonstrated a significant positive relationship between collegial school management and teaching, learning, and students' knowledge and skills.

\section{Disruptive behaviors}

Disruptive behaviors are meant to be one of the challenges in effective teaching, learning as well as school management. Research suggests that the prevention of disruptive behaviors, disciplinary methods, lower-quality classroom teaching, disorganized classroom, school regulations, and student misbehavior are factors in teacher burnout and quality of school management (Jones et al., 2013; Allen, 2010; Public Agenda, 2004). Effective managers can help students that have low self-esteem, dislike school, and teachers, show disrupted behaviors, and have poor academic skills (Matus, 2001), meanwhile, classroom management skills are required to treat disruptive behaviors of students (Horwitz, 2005). Interaction management makes the teaching-learning process lively and happy (Sutama et al., 2012), and create a healthy learning atmosphere without disruptive behaviors (Morales, 2001). Continuous assessment (Balla, 2014), the leadership skills (Pelsma \& Neufeld, 2002), and learning individually, learning from others and learning by doing (Jake \& Sheri, 2007), support interaction, learning, and critical thinking, as well as contribute to minimizing disruptive behaviors. Time constraints and lack of teamwork (Magsino \& Opulencia, 2015), as well as class size (Best, 2005) influence negatively on the prevention of disruptive behaviors. Evaluation model on learning management of teachers (Penprapa et al., 2012), concentrating on the prevention of disruptive behaviors or classroom management efforts (Roscoe \& Orr, 2010), and improvement in teachers' qualification (Erdogan et al., 2010) overcome classroom management problems. The best efforts at classroom management, as well as simulation games, can contribute to reduction in student disruptive behavior (Murphy, \& Van Brunt, 2018; Floress, Rock, \& Hailemariam, 2017). The behavior-specific praise of students, high-probability request sequence, precorrection activity, active supervision, instructional choice, and teaching feedback, as well as good behavior game, can be resulted in a decreased number of student disruptive behaviors (Freeman, 2018: Groves, \& Austin, 2019; Rubow, Vollmer, \& Joslyn, 2018). The positive teacher behaviors, as well as professional development, produced significant improvements in reductions in disruptive behavior (Cook et al., 2018; Bradshaw et al., 2018). In conclusion, the investigation of the relationship between school 
management and the prevention of disruptive behaviors, as resulted in previous research, is important. Based on the previous research, it is hypothesized that:

Hypothesis \# 1: Prevention of disruptive behaviors has been explained by the collegial school management.

\section{Students' life skills}

Collegial school management is supposed to be an important variable that impacts students' life skills, as well. Learning as a part of teaching (Lundström, 2016), skills in motivating and managing others, and effective group leadership are essential in improving students' life skills (Andrew, 2004), meanwhile, students prefer active over passive learning (Betty, 2010). Collegial school management, higher-level knowledge, information-based skills, and communication skills are most valued and vital to students' knowledge and skills (Kleckner \& Marshall, 2014; Boyles, 2012). The living skills (Dickson and Jepsen, 2007), counseling competencies (Swank et al., 2012), as well as the majority of the competencies and roles (Dimmock et al., 2013), showed improved functioning on measures of school management and social competency. Collegial school management, as well as a tremendous amount of academic and soft skills (Marilyn, 2013), enhances students' skills (Ferguson, 2016). Wamdeo and Jebson (2013) revealed the inter-relationship between mathematics skills and the advancement of humans in life, meanwhile, Nigmatov and Nugumanova (2015) concluded that effective school management stimulates the development of students' life skills. Prince, Ho, and Hansen (2010) indicated that the living skills program improved functioning overtime on all measures of school management and social competency. Education programme management as well as perceiving basic life skills concept influence students' skills (Lee, \& Lee, 2019; Yildirim, 2019). The school manager's communicative skill, as well as project-based support developing of multiple life skills (Ali, 2019; Meyer, \& Wurdinger, 2016). School administration, development of productive mindsets and student empowerment play an important role in improvement of multiple students's skills (Mpaata, \& Mpaata, Lane, 2019; Kourmousi, 2018). In conclusion, the study of the relationship between school management and students' life skills, as resulted in previous research, is important. Based on the previous work, it is hypothesized that:

Hypothesis \# 2: Students' life skills have been explained by the collegial school management.

\section{Methodology}

\section{Method and design}

The method used in the research was the quantitative approach. The quasi-experimental research design was used to test the research hypothesis. The non-equivalent 
control group posttest only design was selected to be used in the study. The collegial school management was selected to be used as a manipulated variable to measure its effect on the prevention of disruptive behaviors and students' life skills. The experimental and control groups of respondents were selected using existed teachers and the principals in lower secondary education schools in downtown and suburban parts of the capital city. The teachers and the principals of the experimental group were trained primarily using four modules with the main knowledge, skills and competencies in school management. Meanwhile, the teachers and the principals of the control group were not trained on this topic.

\section{Sample and data collection}

The cluster samples of the research have been compounded by lower secondary teachers and principals' experimental group ( $\mathrm{N}=115)$ of downtown schools of the capital city, and lower secondary teachers and principals' control group $(\mathrm{N}=109)$ of suburban schools of the capital city. The experimental group was created by teachers and principals of downtown schools in the capital city. The control group was created by teachers and principals of suburban schools in the capital city. The selecting criteria of respondents include: (1) they were full-time teachers, (2) they received at least 3-rd grade of qualification, (3) they had not less than ten years teaching experience, (4) they participated at least one time at different levels of school management. A breakdown of the cluster random sample of the experimental group included 88 females (76.5\%), and 27 (23.5\%) males; meanwhile, the cluster random sample of the control group is composed of 69 females (63.3\%), and 40 (36.7\%) males.

Relating to teaching profile, experimental groups of respondents was composed by 20 (17.4\%) languages teachers, 28 (24.3\%) natural sciences teachers, 26 (22.6\%) social sciences teachers, 20 (17.4\%) mathematics teachers, 14 (12.2\%) art and physical education teachers, and 7 (6.1\%) other teachers. Meanwhile, a breakdown of control group of respondents include 17 (15.6\%) languages teachers, 27 (24.8\%) natural sciences teachers, 26 (23.9\%) social sciences teachers, 19 (17.4\%) mathematics teachers, $12(11.0 \%)$ art and physical education teachers, and 8 (7.3\%) other teachers. Relating to teaching experience, experimental groups of respondents was composed by 23 respondents (20.0\%) that had not less than ten years experience, 34 (29.6\%) had up to thirty years experience, 43 (37.4\%) had from 20 - 30 years experience and 15 (13.0\%) had over 30 years experience. A breakdown of the control group of respondents include 19 respondents (17.4\%) that had not less than ten years experience, 37 (33.9\%) had up to thirty years experience, $42(38.5 \%)$ had from 20-30 years experience and 11 (10.1\%) had over 30 years experience.

A structured questionnaire was used to gather data for school management, prevention of disruptive behaviors, as well as students' life skills variables. The structured questionnaire is based on Crowe- associates, (2013), and is adapted, piloted and administered by the researcher. Alfa Cronbach's values of questionnaire scales vary from .084 to .089 confirming the quite good value of reliability. 


\section{Analysis}

The central tendency and frequency values were used to describe the school management, prevention of disruptive behaviors, as well as students' life skills for both, experimental and control groups. The relationship between school management and the prevention of disruptive behaviors and students'life skills was investigated for the experimental and control group using Spearman's rho correlation coefficient. The prediction of the prevention of disruptive behaviors and students'life skills levels by the school management was investigated by linear bivariate regression. The assumption testing was conducted to check for normality, linearity, outliers, as well as the homogeneity of variance-covariance matrices and multicollinearity, with no violations noted.

\section{Results and discussion}

\section{Descriptive statistics}

\section{Collegial school management}

The central tendency data for the experimental group of respondents $(M=3.54$; $\mathrm{SD}=.121)$, and for the control group $(\mathrm{M}=3.0 ; \mathrm{SD}=.078)$ indicate that there is a medium to a high level of collegial school management, although there are differences between downtown and suburb group. The frequencies of collegial school management show that there is a $12.1 \%$ difference between experimental and control groups at a low level, and $3.3 \%$ difference in high level. Therefore, downtown schools reported higher values of collegial school management compared to suburban schools.

\section{Prevention of disruptive behaviors}

The central tendency data for the experimental group $(\mathrm{M}=4.0 ; \mathrm{SD}=.013)$, and for the control group of respondents $(\mathrm{M}=3.89 ; \mathrm{SD}=1.105)$ show that there is a medium to a high level of prevention of disruptive behaviors, although there are differences between downtown and suburb group. The frequencies for the prevention of disruptive behaviors point out that there is a $17.3 \%$ difference between the experimental and control group at a low level, and $87 \%$ difference in high level. Therefore, downtown schools reported significantly higher values of prevention of disruptive behaviors compared to suburban schools.

\section{Students' life skills}

The central tendency data for the experimental group of respondents $(M=4.0$; $\mathrm{SD}=.077)$, and for the control group $(\mathrm{M}=3.59 ; \mathrm{SD}=1.011)$ show that there is a medium to a high level of students' life skills, although there are differences between downtown and suburb group. The frequencies for students' life skills indicate that there is a $9.1 \%$ difference between the experimental and control group at a low level and a $94 \%$ difference in high level. Therefore, downtown schools reported significantly higher values of students' life skills compared to suburban schools. 


\section{Inferential statistics}

Test of Hypothesis

H \# 1: Prevention of disruptive behaviors has been explained by the collegial school management.

Table 1

Spearman's rho correlation outputs between collegial school management and the prevention of disruptive behaviors

Correlations

\begin{tabular}{llcccc}
\hline $\begin{array}{c}\text { Independent } \\
\text { Variable }\end{array}$ & $\begin{array}{c}\text { Dependent } \\
\text { variable }\end{array}$ & $\begin{array}{c}\text { Spearman's rho } \\
\text { correlation }\end{array}$ & $\mathbf{P}$ & $\mathbf{N}$ & $\begin{array}{c}\text { Respondents' } \\
\text { groups }\end{array}$ \\
\hline $\begin{array}{l}\text { Collegial } \\
\text { school man- } \\
\text { agement }\end{array}$ & $\begin{array}{l}\text { Prevention } \\
\text { of disruptive } \\
\text { behaviors }\end{array}$ & .337 & $\mathrm{p}<.005$ & 115 & Experimental \\
\hline
\end{tabular}

The outputs of Spearman's rho correlation indicate that there is a low up to medium positive correlation between collegial school management and prevention of disruptive behaviors variables, rho $=.337, \mathrm{n}=115, \mathrm{p}<.005$ for experimental group, and for control group: rho $=.120, \mathrm{n}=109, \mathrm{p}<.005$. The value of correlation, for the experimental and control group, points out that increasing collegial school management values would increase the prevention of disruptive behaviors, although there are differences between the downtown and suburb group. Thus, collegial school management correlates positively with the prevention of disruptive behaviors.

Table 2

Regression outputs between collegial school management and the prevention of disruptive behaviors

Model Summary

\begin{tabular}{llcccc}
\hline \multicolumn{1}{c}{ Predictors } & $\begin{array}{c}\text { Dependent } \\
\text { variable }\end{array}$ & R & R Square & Sig. F Change & $\begin{array}{c}\text { Respondents' } \\
\text { groups }\end{array}$ \\
\hline $\begin{array}{l}\text { Collegial } \\
\text { school } \\
\text { management }\end{array}$ & $\begin{array}{l}\text { Prevention } \\
\text { of disruptive } \\
\text { behaviors }\end{array}$ & .321 & .103 & .001 & Experimental \\
\hline
\end{tabular}

The regression outputs show that the total variance of prevention of disruptive behaviors levels explained by collegial school management is $10.3 \%, \mathrm{~F}(1, .378), \mathrm{p}<.005$ for experimental group, and $1.7 \%, \mathrm{~F}(1, .317), \mathrm{p}<.005$ for control group; the other variance may be explained by other variables. The control measure in the model is statistically significant with higher standardized beta values for experimental group: beta $=-.129$; $\mathrm{p}<.005$ ), and for control group: (beta $=.321 ; \mathrm{p}<.005$ ). There are differences in the total variance of prevention of disruptive behaviors levels explained by collegial school management between downtown and suburban schools, although there is the same 
tendency. Therefore, collegial school management predicts the prevention of disruptive behaviors. The result was consistent with previously literature works, who argued that collegial school management influences the prevention of disruptive behaviors (Senlik, 2013; Prendergast and O’Meara, 2016; Handal et al., 2015; Babatunde, 2015; Jake and Sheri, 2007). In conclusion hypothesis \# 1: Prevention of disruptive behaviors has been explained by the collegial school management, is been supported.

H\# 2: Students ' life skills have been explained by the collegial school management

Table 3

Spearman's rho correlation outputs between collegial school management and students' life skills

\section{Correlations}

\begin{tabular}{llcccc}
\hline $\begin{array}{c}\text { Independent } \\
\text { Variable }\end{array}$ & $\begin{array}{c}\text { Dependent } \\
\text { variable }\end{array}$ & $\begin{array}{c}\text { Spearman's rho } \\
\text { correlation }\end{array}$ & $\mathbf{P}$ & $\mathbf{N}$ & $\begin{array}{c}\text { Respondents' } \\
\text { groups }\end{array}$ \\
\hline $\begin{array}{l}\text { Collegial } \\
\text { school } \\
\text { management }\end{array}$ & $\begin{array}{l}\text { Students' life } \\
\text { skills }\end{array}$ & .215 & $\mathrm{p}<.005$ & 115 & Experimental \\
\hline
\end{tabular}

The Spearman's rho correlation results show that there is a low positive correlation between collegial school management and students' life skills, rho $=.215, \mathrm{n}=115, \mathrm{p}<.005$ for experimental group, and for control group: rho $=.220, \mathrm{n}=109, \mathrm{p}<.005$, with high levels of collegial school management associated with high levels of students' life skills. The value of correlation, for the experimental and control group, points out that increasing collegial school management values would increase the life skills of students, with no differences between downtown and suburb groups. Thus, collegial school management correlates positively with students' life skills.

Table 4

Regression outputs between collegial school management and students' life skills

\begin{tabular}{llcccc}
\multicolumn{1}{c}{ Predictors } & $\begin{array}{l}\text { Dependent } \\
\text { variable }\end{array}$ & R & R Square & Sig. F Change & $\begin{array}{c}\text { Respondents' } \\
\text { groups }\end{array}$ \\
\hline $\begin{array}{l}\text { Collegial } \\
\begin{array}{l}\text { school } \\
\text { management }\end{array}\end{array}$ & $\begin{array}{l}\text { Students' life } \\
\text { skills }\end{array}$ & .236 & .055 & .003 & Experimental \\
\hline
\end{tabular}

The regression outputs show that the total variance of students' life skills levels explained by collegial school management is $5.5 \%, F(1, .622), p<.005$ for experimental group, and $1.0 \%, F(1, .224), p<.005$ for control group. The other variance may be explained by extraneous variables. The control measure in the model is statistically significant recording higher standardized beta values for experimental group: beta $=-.129 ; \mathrm{p}<.005$ ), and for control group: (beta $=.321 ; \mathrm{p}<.005$ ). There are differences in the total variance of 
students' life skills levels explained by collegial school management between downtown and suburban schools, although there is the same tendency. Therefore, collegial school management predicts students' life skills. The result was consistent with previously works, who argued that collegial school management influences students 'life skills (Briesch et al., 2013; Robacker et al., 2016; Riaz, 2015; Jensen et al., 2015; Wang et al., 2016; Hoidn and Olbert-Bock, 2016; Harrris, 2013; Kunter et al., 2013; Kendziora and Yoder, 2016). In conclusion hypothesis \# 2: Students 'life skills have been explained by the collegial school management, is been supported.

\section{Conclusions and implications}

One limitation should be acknowledged as part of the conclusions of the study. The measurement of collegial school management, prevention of disruptive behaviors, and students' life skills is made with self- reported instruments. The research aimed to study the effects of collegial school management on the prevention of disruptive behaviors and students' life skills. The prior assumption was that collegial school management influence the prevention of disruptive behaviors, and students' life skills.

The results showed that there are higher levels of collegial school management, prevention of disruptive behaviors, and students' life skills in downtown schools compared to suburban schools. The study found out that collegial school management is correlated positively with the prevention of disruptive behaviors, and students' life skills; although there are differences between downtown and suburb group. It is found that the total variance of prevention of disruptive behaviors and students' life skills levels explained by collegial school management is relatively a low percentage, although there are differences between downtown and suburban schools. The collegial school management predicts the prevention of disruptive behaviors and students' life skills much more for downtown schools than for suburban schools.

The study's results, supported by other investigators about the influence of collegial school management on the prevention of disruptive behaviors and students' life skills have powerful implications for future research. The future studies should investigate the impact of other variables on the prevention of disruptive behaviors, and students' life skills. The results of this study also have key implications in practice. The important support should design to empower teachers and principals because it is confirmed by this study that collegial school management influence the prevention of disruptive behaviors, and students' life skills. In all, the findings of this study intensify theoretical and practical understanding as collegial school management is an important variable that supports the prevention of disruptive behaviors, and students' life skills. 


\section{References}

Abulibdeh, E. S. (2013). Using Social Media in the Classroom: Reflecting Lecturer's Pedagogical Approach and Students Intrinsic Motivation. Turkish Online Journal of Distance Education, 14(4), 83-98.

Akgun, S., \& Araz, A. (2014). The Effects of Conflict Resolution Education on Conflict Resolution Skills, Social Competence, and Aggression in Turkish Elementary School Students. Journal of Peace Education, 11(1), 30-45.

Akin, S., Yildirim, A., \& Goodwin, A. L. (2016). Classroom Management through the Eyes of

Elementary Teachers in Turkey: A Phenomenological Study. Educational Sciences: Theory and Practice, 16(3), 771-797.

Ali, Ö. (2019). Study of the Relationship between School Managers' Communicative Skills and Schools' Atmosphere. Journal of Education and Learning, 8(2), 145-164.

Allen, P. K. (2010). Classroom Management, Bullying, and Teacher Practices. The Professional Educator, 34(1), 1-15.

Babatunde, E. G. (2015). Primary School Environment Trend, Class-Ratio and Head Teachers

Overcrowded Classrooms Management Strategies in Northern Senatorial District of Ondo State, Nigeria. Journal of Education and Practice, 6(22), 4-9.

Balla, E. (2014). Students' Assessment and Prevention of disruptive behaviors: A Critical Approach. European Journal of Sustainable Development, 3(3), 323-328.

Best, L. (2005). Class Size and the Goals of the Writing Course: Exploring Classroom Management Strategies. Research \& Teaching in Developmental Education, 21(2), 73-79.

Boyles, T. (2012). 21st Century Knowledge, Skills, and Abilities and Entrepreneurial Competencies: A Model for Undergraduate Entrepreneurship Education. Journal of Entrepreneurship Education, 15, 41-57.

Bradshaw, C. P., Pas, E. T., Bottiani, J. H., Debnam, K. J., Reinke, W. M., Herman, K. C., \& Rosenberg, M. S. (2018). Promoting Cultural Responsivity and Student Engagement through Double Check Coaching of Classroom Teachers: An Efficacy Study. School Psychology Review, $47(2), 118-134$.

Breslin, G., Murphy, M., McKee, D., Delaney, B., \& Dempster, M. (2012). The Effect of Teachers Trained in a Fundamental Movement Skills Programme on Children's Self-Perceptions and Motor Competence. European Physical Education Review, 18(1), 114-126.

Briesch, A. M., Hemphill, E., \& Daniels, B. (2013). Check Your SLANT: Adapting Self-Management for Use as a Class-Wide Intervention. School Psychology Forum, 7(2), 29-39.

Bush, T. (1986). Theories of Educational Management. London, Harper, and Row.

Bush, T. (1995). Theories of Educational Management. Second edition. London, Paul Chapman Publishing.

Bush, T. (2003). Theories of Educational Management. Third edition. London, Sage. 
Bush, T., Glover, D. (2016). School Leadership and Management in South Africa: Findings from a Systematic Literature Review. International Journal of Educational Management, 30(2), 211-231.

Conn, K. (2002). When School Management Companies Fail: Righting Educational Wrongs. Journal of Law and Education, 31(3), 245-269.

Cook, C. R., Fiat, A., Larson, M., Daikos, C., Slemrod, T., Holland, E. A., Thayer, A. J., \& Renshaw, T. (2018). Positive Greetings at the Door: Evaluation of a Low-Cost, High-Yield Proactive Classroom Management Strategy. Journal of Positive Behavior Interventions, 20(3), 149-159.

Crowe- associates (2013). Leadership Styles Questionnaire. Retrieved from www.crowe-associates. co.uk/wp.../2013/.../Leadership-Styles-Questionnaire-2013.doc. January 20, 2017.

Crowe- associates (2013). Leadership Styles Questionnaire. Retrieved from www.crowe-associates. co.uk/wp.../2013/.../Leadership-Styles-Questionnaire-2013.doc. Accessed on June 17, 2018.

Deckman, S. L. (2017). Managing Race and Race-ing Management: Teachers' Stories of Race and Classroom Conflict. Teachers College Record, 119(12), 1-40.

Delman, D. J. (2011). Systemize Classroom Management to Enhance Teaching and Learning. Education Digest: Essential Readings Condensed for Quick Review, 77(2), 56-57.

Dickson, L. G., \& Jepsen, A. D. (2007). Multicultural Training Experiences as Predictors of Multicultural Competencies: Students' Perspectives. Counselor Education and Supervision, 47(2), 76-95.

Dimmock, K., Breen, H., \& Walo, M. (2013). Management Competencies: An Australian Assessment of Tourism and Hospitality Students. Journal of the Australian and New Zealand Academy of Management, 9(1), 12-26.

Dou, D., Devos, G., \& Valcke, M. (2017). The Relationships between the School Autonomy Gap, Principal Leadership, Teachers' Job Satisfaction, and Organizational Commitment. Educational Management Administration \& Leadership 2017, 45(6), 959-977.

Ee, J., \& Ong, C. W. (2014). Which Social-Emotional Competencies Are Enhanced at a Social Emotional Learning Camp?. Journal of Adventure Education and Outdoor Learning, 14(1), 24-41.

Erdogan, M., Kursun, E., Sisman, G. T., Saltan, F., Gok, A., \& Yildiz, I. (2010). A Qualitative Study on Classroom Management and Classroom Discipline Problems, Reasons, and Solutions: A Case of Information Technologies Class. Kuram ve Uygulamada Egitim Bilimleri, 10(2), 881-891.

Ferguson, M. (2016). ESSA Opens School Door to Social-Emotional Learning: The Every Student Succeeds Act Offers Educators an Opportunity to Recognize the Importance of Developing the Social-Emotional Skills of Their Students as Tools for Academics and Life. Phi Delta Kappan, 97(8), 74-75.

Floress, M. T., Rock, A. L., \& Hailemariam, A. (2017). The Caterpillar Game: A Classroom Management System. Psychology in the Schools, 54(4), 385-403.

Freeman, J. (2018). Effective Low-Intensity Strategies to Enhance School Success: What Every Educator Needs to Know-A Closing Commentary. Beyond Behavior, 27(3), 175-176. 
Groves, E. A., \& Austin, J. L. (2019). Does the Good Behavior Game Evoke Negative Peer Pressure? Analyses in Primary and Secondary Classrooms. Journal of Applied Behavior Analysis, 52(1), 3-16.

Hadromi, R. M., \& Soesanto, K. T. J. (2015). The Development of Productivity Practical Management Model at Automotive Mechanical Technology Skill Program in Semarang Vocational Schools, Indonesia. International Education Studies, 8(5), 101-110.

Hamel, G., \& Breen, B. (2008). The Future of Management. Journal of Applied Management and Entrepreneurship, 13(2), 88-101.

Handal, B., Watson, K., \& Maher, M. (2015). Multi-Positioning Mathematics Class Size: Teachers' Views. International Journal of Mathematics Teaching and Learning, Apr 2015.

Harrris, C. R. (2013). Perceptions of Students at a Rural Mississippi Community College Regarding Employability. ProQuest LLC, Ph.D. Dissertation, Mississippi State University.

Hoidn, S., \& Olbert-Bock, S. (2016). Learning and Teaching Research Methods in Management Education: Development of a Curriculum to Combine Theory and Practice-A Swiss Case. International Journal of Educational Management, 30(1), 43-62.

Horwitz, K. E. (2005). Classroom Management for Teachers of Japanese and Other Foreign Languages. Foreign Language Annals, 38(1), 56-64.

Ifegbesan, A. (2010). Exploring Secondary School Students' Understanding and Practices of Waste

Management in Ogun State, Nigeria. International Journal of Environmental and Science Education, 5(2), 201-215.

Jagpreet, K. (2015). Impact of Home and School Environment on Life Skills among Adolescents. International Journal of Psychology Research, 10(4), 41-52.

Jensen, E., Skibsted, E. B., \& Christensen, M. V. (2015). Educating Teachers Focusing on the Development of Reflective and Relational Competencies. Educational Research for Policy and Practice, 14(3), 201-212.

Jones, M. S., Bouffard, M. S., \& Weissbourd, R. (2013). Educators' Social and Emotional Skills Vital to Learning: Social and Emotional Competencies Aren't Secondary to the Mission of Education, but Are Concrete Factors in the Success of Teachers, Students, and Schools. Phi Delta Kappan, 94(8), 62-65.

Kendziora, K., \& Yoder, N. (2016). When Districts Support and Integrate Social and Emotional Learning (SEL): Findings from an Ongoing Evaluation of Districtwide Implementation of SEL. Education Policy Center at American Institutes for Research.

Kinloch, K. E. (2013). A Comparison of Teacher Classroom Management Practices and Presage Variables on High and Low Performing Elementary Schools. ProQuest LLC, Ed.D. Dissertation, South Carolina State University.

Kleckner, M. J., \& Marshall, C. R. (2014). Critical Communication Skills: Developing Course Competencies to Meet Workforce Needs. The Journal of Research in Business Education, 56(2), 59-81.

Kourmousi, N., Markogiannakis, G., Tzavara, C., Kounenou, K., Mandrikas, A., Christopoulou, E., \& Koutras, V. (2018). Students' Psychosocial Empowerment with the 'Steps for Life' Personal 
and Social Skills Greek Elementary Programme. International Electronic Journal of Elementary Education, 10(5), 535-549.

Kraebber, S. L., \& Greenan, J. P. (2012). The Relationship between Self-Concept and Self-Ratings of Generalizable Skills of Students in Postsecondary Career and Technical Programs. Journal of Career and Technical Education, 27(1), 15-33.

Kumar, M. (2011). Management Education in India: Issues \& Challenges. Journal of Management and Public Policy, 3(1), 5-14.

Kunter, M., Klusmann, U., Baumert, J., Richter, D., Voss, T., \& Hachfeld, A. (2013). Professional Competence of Teachers: Effects on Instructional Quality and Student Development. Journal of Educational Psychology, 105(3), 805-820.

Lakova, A., \& Chaklikova, A. (2016). Management of Students' Independent Work through Project Technology in Foreign Language Education. International Journal of Environmental and Science Education, 11(15), 7888-7898.

Lane, M., Moore, A., Hooper, L., Menzies, V., Cooper, B., Shaw, N., \& Rueckert, C. (2019). Dimensions of Student Success: A Framework for Defining and Evaluating Support for Learning in Higher Education. Higher Education Research and Development, 38(5), 954-968. Lee, G. Y., \& Lee, D. Y. (2019). Effects of a Life Skills-Based Sexuality Education Programme on the Life-Skills, Sexuality Knowledge, Self-Management Skills for Sexual Health, and Programme Satisfaction of Adolescents. Sex Education: Sexuality, Society and Learning, 19(5), 519-533.

Lundström, M. (2016). Always Learning: A Swedish Perspective. Delta Kappa Gamma Bulletin, $82(4), 23-43$.

Mac Cobb, S., Fitzgerald, B., \& Lanigan-O’Keeffe, C. (2014). The Alert Program for SelfManagement of Behaviour in Second Level Schools: Results of Phase 1 of a Pilot Study. Emotional \& Behavioural Difficulties, 19(4), 410-425.

Magsino, A. R., \& Opulencia, Y. K. (2015). Entrepreneurial Intentions among Entrepreneurial Management Students Class 2014: A Qualitative Longitudinal Study. Researchers World, 6(1), 93-99.

Mampane, S. T. (2017). Training Middle Managers of South African Public Schools in Leadership and Management Skills. Bulgarian Comparative Education Society, Paper prepared for the Annual International Conference of the Bulgarian Comparative Education Society (BCES) (15th).

Marilyn, R. (2013). Preparing for Life "Beyond Academe": Professional Skills Development for Graduate Students in Canadian Universities. English Studies in Canada, 39(4), 12-27.

Matus, D. E. (2001). Traditional Classroom Management Revisited in the Urban School. American Secondary Education, 30(1), Fall 2001.

Meyer, K., \& Wurdinger, S. (2016). Students' Perceptions of Life Skill Development in ProjectBased Learning Schools. Journal of Educational Issues, 2(1), 91-114.

Morales, A. C. (2001). Discipline: Applicable techniques for student teachers. Education, 101, 115-117. 
Mpaata, K. A., \& Mpaata, Z. (2019). The Leadership Role of Secondary School Head Teachers in Delivering Integrative Quality Education in Uganda. International Journal of Educational Leadership and Management, 7(2), 203-230.

Murphy, A., \& Van Brunt, B. (2018). Addressing Dangerous Behavior in the Classroom. Educational Leadership, 76(1), 66-70.

Nigmatov, G. Z., \& Nugumanova, N. L. (2015) Methods for Developing Technological Thinking Skills in the Pupils of profession-oriented Schools. Asian Social Science, 11(8), 27-36.

OECD (2017). Teaching and Learning International Survey (TALIS). Teacher Questionnaire. Retrieved from: http://www.oecd.org/. January 20, 2017.

Ohrt, J., Webster, L., \& De La Garza, M. (2015). The Effects of a Success Skills Group on Adolescents' Self-Regulation, Self-Esteem, and Perceived Learning Competence. Professional School Counseling, 18(1), 169-178.

Onzonol, S. I. (2010). Management Education: The Best is Yet to Come. Essays of GFME Board Members, January.

Oyono, T. M. (2016). Self-Centered Management Skills and Knowledge Appropriation by Students in High Schools and Private Secondary Schools of the City of Maroua. Journal of Education and Practice, 7(29), 92-97.

Padmaja, C. V. (2012). Classroom Management: An Approach. IUP Journal of English Studies, $7(2), 39-42$.

Payne, K., \& Edwards, B. (2010). Service-Learning Enhances Education for Young Adolescents: Service Learning Can Reinforce Learning for Middle Grades Students, Launch them into the Process for Independence in a Prosocial Manner, and Develop the Competencies and Civic Skills They Need as They Move toward Adulthood. Phi Delta Kappan, 91(5), 27-30.

Pelsma, M. D., \& Neufeld, J. P. (2002). The Teaching of Leadership, Cooperation, and Communication in a Class Entitled: Management of Counseling Programs. TCA Journal, 30(1), 11-19.

Penprapa, K., Songsak, P., \& Nawamin, P. (2012). The Development of an Evaluation Model on Learning Management of Foreign Language Teachers in the World-Class Standard Primary Schools. Canadian Social Science, 8(6), 60-67.

Prendergast, M., \& O’Meara, N. (2016). Assigning Mathematics Instruction Time in Secondary Schools: What Are the Influential Factors?. International Journal of Mathematical Education in Science and Technology, 47(8), 1137-1155.

Prince, C. K., Ho, A. E., \& Hansen, B. S. (2010). Effects of a school-based program to improve adaptive school behavior and social competencies along with elementary school youth: The Living Skills Program. Journal of Research in Character Education, 8(2), 27-39.

Public Agenda (2004). Teaching Interrupted. Do Discipline Policies in Today's Public School Foster the Common Good? ISBN: 1-889483-85-0. www.Public Agenda.org. Retrieved from: https:// www.publicagenda.org/files/teaching_interrupted. pdf. May 22, 2017. 
Reddy, L. A., Dudek, C. M., Rualo, A. J., \& Fabiano, G. A. (2016). Concurrent Validity of the Classroom Strategies Scale-Teacher Form: A Preliminary Investigation. Educational Assessment, 21(4), 267-277.

Reinke, W. M., Herman, K. C., \& Dong, N. (2014). The Incredible Year Teacher Classroom Management Program: Initial Findings from a Group Randomized Control Trial. Society for Research on Educational Effectiveness.

Riaz, M. (2015). School Physics Teacher Prevention of Disruptive Behaviors, Laboratory Practice, Student Engagement, Critical Thinking, Cooperative Learning and Use of Simulations Effects on Student Performance. ProQuest LLC, Ed. D. Dissertation, Dowling College.

Robacker, C. M., Rivera, C. J., \& Warren, S. H. (2016). A Token Economy Made Easy through ClassDojo. Intervention in School and Clinic, 52(1), 39-43.

Roscoe, K., \& Orr, K. (2010). Frontloading Classroom Management: How to Plan for the First Class. The Science Teacher, 77(5), 43-48.

Rubow, C. C., Vollmer, T. R., \& Joslyn, P. R. (2018). Effects of the Good Behavior Game on Student and Teacher Behavior in an Alternative School. Journal of Applied Behavior Analysis, 51(2), 382-392.

Sanjoy, R., Ashutosh, G., \& Bharat, K. (2014). CSR and Management Studies: An Exploratory Research How to Make Student's Attitude Positive for Social Accounting. Advances in Management, 7(4), 31-37.

Schulze, M. A. (2016). Self-Management Strategies to Support Students with ASD. TEACHING Exceptional Children, 48(5), 225-231.

Senlik, Y. (2013). Teacher Classroom Management Ratings at Concept Charter Schools. ProQuest LLC, Ed.D. Dissertation, Illinois State University.

Shavega, T. J., van Tuijl, C., \& Brugman, D. (2015). Teachers' Perception of Children's Behavioral Adjustment in Tanzanian Preprimary Schools and Their Relationship to Teachers' Cultural Beliefs Regarding Obedience, Cooperation, and Play. Infants and Young Children, 28(1), 88-108. Sutama S., Narimo, S., \& Haryoto H. (2012). Mathematics Learning Management at Elementary School Post Merapi Eruption. International Journal of Education, 4(4), 192-203.

Swank, M. J., Lambie, W. G., \& Witta, L. E. (2012). An Exploratory Investigation of the Counseling Competencies Scale: A Measure of Counseling Skills, Dispositions, and Behaviors. Counselor Education and Supervision, 51(3), 189-206.

Tas, S. (2011). Management Philosophies of Primary School Principals. Education, 131(3), 565-579. Thompson, A. M. (2014). A Randomized Trial of the "Self-Management Training and Regulation Strategy" for Disruptive Students. Research on Social Work Practice, 24(4), 414-427.

Tsai, H., \& Liu, S. (2015). Relationships between Time-Management Skills, Facebook Interpersonal Skills, and Academic Achievement among Junior High School Students. Social Psychology of Education: An International Journal, 18(3), 503-516.

Turner, R., Matthews, G., Ashcroft, L., \& Farrow, J. (2007). Senior Management and the Provision of Libraries in Independent Schools in England and Wales. School Libraries Worldwide, 13(1), 1-21. 
Walk, R. D. Jr. (2003). How Educational Management Companies Serve Charter Schools and Their Students. Journal of Law and Education, 32(2), 12-19.

Wamdeo, Y., Y., \& Jebson, R., S. (2013). Development and Validation of Competency Skills Test in Mathematics for Junior Secondary Schools in Borno State, Nigeria. International Journal of University Teaching and Faculty Development, 4(2), 31-49.

Wang, Li-Yi., Jen-Yi, Li., Tan, L., Tan, I., Lim, X., \& Wu, B. S. (2016). Unpacking High and Low Efficacy Teachers' Task Analysis and Competence Assessment in Teaching Low-Achieving Students in Secondary Schools. Australian Educational Researcher, 43(2), 165-183.

Wirussawa, S., Tesaputa, K., \& Duangpaeng, A. (2016). An Effect of the Learning Environment Management System on Student Quality of Thai Secondary School. International Education Studies, 9(5), 235-246.

$\mathrm{Xu}$, J. (2012). Predicting Students' Homework Environment Management at the Secondary School Level. Educational Psychology, 32(2), 183-200.

Xu, J., \& Corno, L. (2003). School Location, Student Achievement, and Homework Management Reported by Middle School Students. The School Community Journal, 2009, 19(2), 27-43.

Xu, J., \& Corno, L. (2006, March 10). Gender, family help, and homework management reported by rural middle school students. Journal of Research in Rural Education, 21(2), 1-13.

Xu, J., \& Wu, H., (2013). Self-Regulation of Homework Behavior: Homework Management at the Secondary School Level. Journal of Educational Research, 106(1), 1-13.

Xu, X. J. (2006). Middle School Homework Management and Attitudes. Academic Exchange Quarterly, 10(4).

Yang, F., Xu, J., Tan, H., \& Liang, N. (2016). What Keeps Chinese Students Motivated in Doing Math Homework? An Empirical Investigation. Teachers College Record, 118(8), 2016.

Yildirim, G. (2019). The Views of Pre-Service Primary School Teachers Regarding the Concept of "Basic Life Skills" of Life Science Course. Educational Policy Analysis and Strategic Research, 14(3), 64-79.

Zekeri, A., A. (2004). College Curriculum Competencies and Skills Former Students Found Essential to Their Careers. College Student Journal, 38(3), 412-423.

Zhang, X., Anderson, R. C., Morris, J., Miller, B., Nguyen-Jahiel, K. T., Lin, T., Zhang, J., Jadallah, M., Scott, T., Sun, J., Latawiec, B., Ma, S., Grabow, K., \& Hsu, J. Yu-Li (2016). Improving Children's Competence as Decision Makers: Contrasting Effects of Collaborative Interaction and Direct Instruction. American Educational Research Journal, 53(1), 194-223.

Zhu, J., \& Coulson, S. (2007). Designing a Class Activity to Enhance Business Students' Learning of Management Information Systems. Communications of the IIMA, 7(2), 105-114. 


\title{
Kolegialus mokyklos valdymo efektas mokinių igūdžiams gerinti
}

\author{
Dr. Nazmi Xhomara
}

Luarasi universitetas, Informacinių technologijų ir inovacijų fakultetas, Matematikos ir statistikos katedra, Tirana, Rr. e Elbasanit, Nd. 59, H. 1, AL-1010, Albania,nazmi.xhomara@luarasi-univ.edu.al

\section{Santrauka}

Kolegialus mokyklos valdymas, kaip manoma, yra vienas iš svarbių faktorių, turinčių itakos žalingo elgesio prevencijai ir mokinių gyvenimo igūdžiams. Tyrimu siekiama ištirti mokyklos kolegialaus valdymo ịtaką žalingo elgesio prevencijai ir mokinių gyvenimo igūdžiams. Buvo naudojamas kvazieksperimentinis tyrimo dizainas, struktūrizuotas klausimynas ir klasterinè atranka. Tik atlikus testą, buvo pasirinktos neekvivalentiškos kontrolinès grupès. Kolegialus mokyklos valdymas buvo pasirinktas kaip manipuliuojamas kintamasis, kad būtų galima ịvertinti jo poveikį žalingo elgesio prevencijai ir studentų gyvenimo ịgūdžiams. Eksperimentinès ir kontrolinès respondentų grupès buvo atrinktos pasitelkiant esamus mokytojus ir vadovus iš žemesniųjų vidurinio ugdymo mokyklų mieste centre ir priemiesčiuose. Tyrimo metu nustatyta, kad kolegialus mokyklos valdymas yra tiesiogiai susijęs su žalingo elgesio prevencija ir studentų gyvenimo igūdžiais, nors tarp miesto centro ir priemiesčio tiriamųjų grupių yra skirtumų. Nustatyta, kad bendra žalingo elgesio prevencijos ir mokinių gyvenimo ígūdžių lygių dispersija paaiškina palyginti mažą kolegialaus mokyklos valdymo procentą, nors tarp miesto ir priemiesčio mokyklų pastebèta skirtumų.

Esminiai žodžiai: mokyklos valdymas, kolegialus mokyklos valdymas, formalus mokyklos valdymas, žalingų îpročių prevencija, elgesys, gyvenimo igūdžiai. 